\title{
The Biosynthesis of Steroidal Sapogenins by Homogenates of Dioscorea Tubers
}

\author{
Bruce Roark1 and M.P.Morris ${ }^{2}$ \\ INTRODUCTION
}

Several years ago other investigators reported that fermentation for 1 to 21 days of comminuted tubers of Dioscorea led to increased yields of diosgenin $(1,2)^{3}$. It can be reported now that fine comminution alone leads to these same apparent increases, and that fermentation for 1 to 21 days is not necessary to produce increased yields of diosgenin. Evidence has been obtained that a rapid enzymatic synthesis of steroidal compounds takes place in tubers which have been homogenized.

\section{PROCEDURES}

Representative subsamples of a single tuber of $D$. floribunda were analyzed $(3,4)$ after one of the following treatments: 1 , Homogenized fresh with an equal quantity of water and hydrolyzed immediately in $2 \mathrm{~N} \mathrm{HCl} ; 2$, homogenized fresh with an equal quantity of water and rapidly dried to constant weight at $85^{\circ} \mathrm{C}$. before hydrolysis; 3 , killed in autoclave at 15 pounds pressure for 5 minutes, then homogenized with an equal quantity of water and rapidly dried to constant weight at $85^{\circ} \mathrm{C}$. before hydrolysis; 4 , killed by homogenizing with an equal quantity of $2 \mathrm{~N} \mathrm{HCl}$, and hydrolyzed immediately; 5 , sliced but not homogenized, rapidly dried to constant weight at $85^{\circ} \mathrm{C}$., and ground to a fine dust before hydrolysis. The results are presented in the following tabulation showing yields of steroidal sapogenins of identical subsamples of a Dioscorea tuber (D. floribunda):

Trealment of fresh sample before analysis

1, Homogenized in water

2, Homogenized in water and dried

3, Autoclaved, homogenized, and dried

4, Homogenized in $2 \mathrm{~N} \mathrm{HCl}$

5 , Sliced, dried, and ground

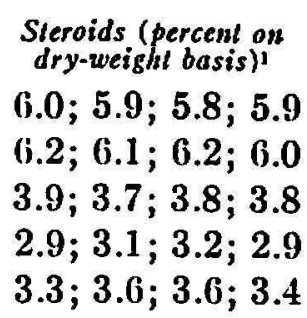

${ }_{1}^{1}$ Determinations on fresh samples weighing $50 \mathrm{gm}$. each. Similar yields were obtained on fresh samples weighing 500 and $1,000 \mathrm{gm}$. The isolated product is a mixture of diosgenin and small amounts of at least three other steroids. Similar results were obtained with $D$. composita.

1 Plant Physiologist, Federal Experiment Station, Mayagüez, P.R. Present address Agricultural Experiment Station, Stoneville, Miss.

2 Chemist, Federal Experiment Station, Mayagüez, P.R. Present address Division of Food, Food and Drug Administration, Washington 25, D. C.

Italic numbers in parentheses refer to Literature Cited p. 120. 


\section{DISCUSSION}

These results demonstrate that the highest yields of sapogenins are obtained when living tubers are homogenized as in methods 1 and 2. Significantly lower yields of sapogenins are obtained from Dioscorea tubers when the endogenous enzyme systems are destroyed by the addition of acid or by heating before the tissue is homogenized as in 3 and 4 .

In a series of separate experiments homogenized tubers were fermented for periods up to 14 days. The yields of sapogenins were not significantly different from the yields of the controls which were assayed immediately after being homogenized.

Further evidence that sapogenins are formed in homogenized tuber tissue was obtained when fresh tubers were homogenized with 1-C ${ }^{14}$-labeled acetate. The mixture was incubated overnight and a radioactive mixture of crude sapogenins was isolated from it. The sapogenins were still significantly radioactive after being crystallized several times from ether-petroleum ether mixtures. The steroids were then acetylated and the acetates were washed with water and recrystallized from petroleum ether. The acetates had approximately the same specific activity as the original steroids.

\section{SUMMARY}

It has been demonstrated that fermentation of comminuted tubers of Dioscorea for 1 to 21 days apparently increases the yields of diosgenin. We find that fine comminution produces the same result without fermentation.

This readily available enzyme system should be useful to workers in several fields. It provides a convenient tool for further studies on the biosynthesis of plant steroids. Furthermore, the incorporation of radioactivity into steroidal sapogenins should simplify the production of radioactive pharmaceutical products which are derived from them.

\section{RESUMEN}

Este valioso sistema enzimático puede tener muchas aplicaciones para trabajar en los más diversos campos cientificos. Sería también, un sistema muy conveniente para futuros estudios sobre la biosintesis de los esteroides en las plantas. Por otra parte, la incorporación de radiactividad dentro de esteroides sapogénicos podría simplificar la producción de aquellos productos farmacéuticos radiactivos derivados de éstos.

\section{LITERATURE CITED}

1. Gould, David H., Hershberg, Emanuel B., and Clayton, Temple, U.S. Patent 2,774,713, Dec. 18, 1956.

2. Hershberg, Emanuel B., and Gould, David H., U.S. Patent 2,774,714, Dec. 18, 1956.

3. Rothrock, J. W., Hammes, P. A., and McAleer, W. J., Ind. Eng. Chem. 49, 186$88,1957$.

4. Morris, M. P., Roark, Bruce, and Cancel, Bartolome, J. Agr. Food Chem., 6, $856-8,1958$. 